MUST: Journal of Mathematics Education, Science and Technology

Vol. 5, No. 2, Desember 2020 Hal 182-196

DOI: http://doi.org/10.30651/must.v5i2.6190

\title{
PENGARUH MODEL PEMBELAJARAN KOOPERATIF TIPE NHT WITH RANDOM NAME NUMBER TERHADAP HASIL BELAJAR MAHASISWA PADA MATERI ALJABAR ELEMENTER
}

\author{
Eka Susilowati \\ Universitas PGRI Adi Buana Surabaya \\ eka_s@unipasby.ac.id
}

Received 08 October 2020; revised 12 November 2020; accepted 16 November 2020.

\begin{abstract}
ABSTRAK
Motivasi dari penelitian ini adalah kesulitan belajar yang dialami oleh mahasiswa prodi Pendidikan Matematika pada mata kuliah Aljabar Elementer. Sehingga diterapkan model pembelajaran untuk mengatasi permasalahan tersebut, yaitu Model Kooperatif Tipe NHT with Random Name Number. Tujuan penelitian ini diantaranya (1) untuk mengetahui hasil belajar mahasiswa Prodi Pendidikan Matematika Universitas PGRI Adi Buana Surabaya semester Ganjil tahun pelajaran 2019/2020 dengan menerapkan model pembelajaran Kooperatif Tipe NHT with Random Name Number, (2) untuk mengetahui ada atau tidaknya pengaruh model pembelajaran Kooperatif Tipe NHT with Random Name Number terhadap hasil belajar mahasiswa, dan (3) apabila terdapat pengaruh, berapa besar pengaruh model tersebut terhadap hasil belajar mahasiswa. Populasi penelitian ini adalah mahasiswa Prodi Pendidikan Matematika, Universitas PGRI Adi Buana Surabaya, semester Ganjil tahun pelajaran 2019/2020 yang mengikuti mata kuliah Aljabar Elementer. Adapun sampel penelitian adalah kelas 2019 A dan C. Teknik pengumpulan data adalah tes. Metode yang diterapkan pada penelitian ini yaitu pendekatan penelitian kuantitatif menggunakan uji t dengan terlebih dahulu diuji apakah data berdistribusi normal atau tidak, dan homogen atau tidak. Berdasarkan hasil uji t pada data, diperoleh bahwa t-hitung = 0,592041536 < 1.682878002 = t-tabel. Hasil dari penelitian menunjukkan tidak terdapat pengaruh yang signifikan model pembelajaran Kooperatif Tipe NHT with Random Name Number terhadap hasil belajar mahasiswa Prodi Pendidikan Matematika Universitas PGRI Adi Buana Surabaya semester Ganjil tahun pelajaran 2019/2020.
\end{abstract}

Kata kunci: hasil belajar, kooperatif, model pembelajaran, pengaruh, tipe NHT.

\section{ABSTRACT}

The motivation of this study is the learning difficulties experienced by Mathematics Education study program students in Elementary Algebra courses. Thus, a learning model is 
applied to overcome these problems, namely NHT Type Cooperative learning model with Random Name Number. The objectives of this study are (1) to determine the learning outcomes of students in the Mathematics Education Department of Universitas PGRI Adi Buana Surabaya in the odd semester of the 2019/2020 academic year by applying the NHT Type Cooperative learning model with Random Name Number, (2) to determine whether there is an effect of the NHT Type Cooperative learning model with Random Name Number on student learning outcomes, and (3) if there is an effect, how the effect does this model have on student learning outcomes. The population of this study were students of the Mathematics Education Department, Universitas PGRI Adi Buana Surabaya, odd semester of the 2019/2020 academic year who took Elementary Algebra courses. The research sample is class 2019 A and C. The data collection technique is a test. The method applied in this research is a quantitative research approach using the t test by first testing whether the data is normally distributed or not, and is homogeneous or not. Based on the results of the $t$ test on the data, it is found that $t$-count $=0.592041536<1.682878002=t$-table. The results of the study showed that there was no significant effect of the NHT Type Cooperative learning model with Random Name Number on the students learning outcomes in Mathematics Education Department of Universitas PGRI Adi Buana Surabaya in the odd semester of the 2019/2020 academic year.

Keywords: learning outcomes, cooperative, learning models, effect, NHT type.

\section{PENDAHULUAN}

Matematika adalah suatu bidang keilmuan yang dasar dan mempunyai kedudukan yang fundamental pada saat mengembangkan IPTEK (Lestari, Hartono, Purwoko, 2016). Matematika juga menyediakan tempat untuk meningkatkan kompetensi berpikir sesuai logika, sistematik, kritis, kreatif, inovatif, serta meningkatkan perilaku obyektif dan transparan, yang sangat diperlukan untuk menyongsong masa depan yang terus berbenah menjadi lebih baik (Rumapea, 2018). Matematika muncul dikarenakan adanya pemikiran seseorang yang berkaitan dengan ide, proses, dan menalar. Setiap siswa/mahasiswa mempunyai daya logika yang berlainan sehingga berakibat seringkali siswa/mahasiwa kesusahan saat memahami matematika (Rahmiati \& Fahrurrozi, 2016).

Stigma Matematika merupakan hal yang sulit juga masih ada sampai jenjang perguruan tinggi. Kesulitan yang biasa ditemui mahasiswa dikarenakan kurang adanya latihan soal dan hanya mengandalkan apa yang diberikan dosen 
karena dosen menerapkan model pembelajaran konvensional. Model pembelajaran konvensional dikategorikan pembelajaran yang membosankan, dosen memang memiliki peran aktif dalam menyampaikan ilmu, pengetahuan, mempresentasikan keahlian atau melemparkan pertanyaan-pertanyaan, namun mahasiswa hanya merekam dan mencatat apa yang telah disampaikan (Putri, 2017). Kemandirian belajar mahasiswa ikut menjadi penentu tercapainya kesuksesan mahasiswa dalam proses pembelajaran serta memperlihatkan segi positif terhadap proses pembelajaran dan tercapainya hasil belajar yang baik (Arifin \& Herman, 2018). Dosen pun serba salah jika memberikan tugas di kampus tidak cukup waktunya dan tidak menarik bagi mahasiswa, namun jika diminta dikerjakan di rumah, tidak ada jaminan mahasiswa mengerjakan sendiri dan meningkatkan kemandirian mereka dalam belajar. Proses pembelajaran yang diterapkan lebih tertuju pada langkah mengajarkan bukan membelajarkan. Akibatnya, mahasiswa diasumsikan sebagai pelaku yang tidak aktif, hanya menampung segala sesuatu yang diberikan oleh dosen. Dengan demikian, pembentukan karakter yang ada pada pribadi mahasiswa hanya pengetahuan kognitif yang kedalaman pemahamannya masih belum bisa diandalkan.

Perihal ini berdampak pada mahasiswa yang pasif dalam menyampaikan pendapat atau melontarkan pertanyaan (Angraeni \& Puspitasari, 2019). Minimnya prestasi belajar matematika terjadi di banyak perguruan tinggi. Salah satu penyebab sedikitnya prestasi belajar matematika ini yaitu kecocokan model pembelajaran yang diterapkan oleh pendidik/dosen terhadap mahasiswa (Madio, 2016). Akibatnya, dosen didorong untuk dapat mengontrol dan menjalankan proses pembelajaran dengan mempunyai keahlian saat menentukan model dan metode pembelajaran yang disesuaikan dengan sasaran kurikulum dan kemampuan yang dipunyai oleh mahasiswa (Putri, 2017). Pemilihan model pembelajaran yang disesuaikan dengan materi, penggunaan media pembelajaran, strategi pendidik dalam mendesain suasana kelas memiliki peranan penting (Dadri, Dantes, \& Gunamantha, 2019).

Banyak penelitian yang memaparkan model-model pembelajaran untuk dapat memperbaiki hasil belajar mahasiswa sekaligus memaksa mahasiswa untuk berpartisipasi dalam pembelajaran melalui pengalaman tidak hanya menampung 
konsep yang disampaikan pendidik, dan dapat mengintrepretasikan bidang keilmuannya secara mandiri. Pembelajaran yang bisa memaksa secara halus mahasiswa untuk berpartisipasi aktif adalah model pembelajaran kooperatif, karena saat pembelajaran kooperatif ini, mahasiswa dipecah ke dalam kelompokkelompok agar dapat bekerjasama dengan mahasiswa lain dalam memecahkan permasalahan (Bainamus, Hartanto, \& Abdullah, 2017).

Definisi pembelajaran kooperatif secara umum merupakan model pembelajaran yang memanfaatkan sistem pengelompokan mahasiswa dalam kelompok-kelompok kecil, terdiri empat hingga enam orang yang memiliki background kemampuan berbeda (Lakkas, 2018). Model pembelajaran kooperatif terdiri dari berbagai macam variasi, seperti Student Team Achievement Division (STAD), Jigsaw, Teams- Games-Tournaments (TGT), Group Investigation (GI), Rotating Tri Exchange, Group Resume (Suparni, 2017). Beberapa tipe model pembelajaran kooperatif, diantaranya Number Head Together (NHT), Cooperatif Script, Group Investigation, Think Pair Share (TPS), Jigsaw, Snow Ball Throlling, Team Game Tournament (TGT), Think-Talk-Write (TTW), dan Two Stay Two Stray (TS-TS).

Model pembelajaran yang kooperatif yang biasa diterapkan merupakan model pembelajaran kooperatif tipe NHT. Model pembelajaran kooperatif tipe NHT dapat didefinisikan model pembelajaran memecah mahasiswa di kelompokkelompok kecil yang dirancang guna memberikan nomor kepala pada setiap peserta didik di setiap kelompok (Dadri, Dantes, \& Gunamantha, 2019; Sutriningsih, Pratiwi, \& Utami, 2018). Kedua penelitian tersebut menjelaskan bahwa menghasilkan model pembelajaran kooperatif tipe NHT berpengaruh positif. Nurdyanto menjelaskan modifikasi model pembelajaran Kooperatif Tipe NHT dengan pendekatan SPICES Continuing, yaitu Student Centered, Problembased, Integrated, Community oriented, Electives, Systematic, dan Continuing (Nurdyanto, Indana, \& Agustini, 2018). Namun, peneliti menemukan kelemahan dari model pembelajaran tersebut. Kelemahan model pembelajaran Kooperatif Tipe NHT dengan pendekatan SPICES Continuing adalah karena nomor yang diminta maju disebut oleh pendidik, sehingga tidak melatih keberanian bagi peserta didik untuk maju. Pada model pembelajaran Kooperatif Tipe NHT dengan 
pendekatan SPICES Continuing ini, terdapat langkah menyediakan kesempatan kepada anggota kelompok lain yang memiliki nomor sama untuk menyampaikan tanggapan dan berdiskusi. Karena hanya ditujukan yang bernomor sama saja, maka yang lain cenderung tidak akan memperhatikan. Reward bagi peserta didik untuk maju dan memberi tanggapan pun harus nyata, misal ada poin untuk nilai tugas, sehingga mereka antusias untuk maju.

Berdasarkan beberapa kelemahan yang ditemukan pada model pembelajaran Kooperatif Tipe NHT dengan pendekatan SPICES Continuing, peneliti merancang model pembelajaran yang diasumsikan dapat mengatasi kelemahan model pembelajaran Kooperatif Tipe NHT dengan pendekatan SPICES Continuing ini. Model pembelajaran yang dirancang oleh peneliti ini dinamakan model pembelajaran kooperatif tipe NHT with Random Name Number. Langkah-langkah yang menjadi sintaks model pembelajaran kooperatif tipe NHT with Random Name Number adalah

1. Pembagian kelompok

Satu kelompok dibagi menjadi 3 sampai 4 orang agar lebih efektif. Nomor kelompok ditentukan dengan cara berhitung sesuai tempat duduk. Misalkan jumlah satu kelas 32 mahasiswa, maka mulai dari yang duduk di pojok berhitung satu diteruskan sebelahnya hingga delapan, kemudian berhitung satu sampai delapan lagi ke mahasiswa yang duduk di sebelah delapan tadi dan seterusnya. Mahasiswa yang tadi menyebut satu, maka berkelompok dengan mahasiswa yang menyebut nomor satu, dst. Berikutnya, 8 kelompok yang telah terbentuk diberi nama kelompok A, B, C, ..., I dengan tiap kelompok 4 orang karena jumlah satu kelas 32 mahasiswa.

2. Penamaan angka untuk mahasiswa dalam satu kelompok.

Untuk setiap kelompok, anggota kelompok tersebut berhitung kembali untuk menentukan namanya dalam kelompok tsb. Misalkan kelompok A ada empat orang dengan nama Ana, Budi, Cica, dan Dedi, maka mereka berhitung 1 sampai 4. misalkan 1 itu disebut Ana, maka inisial nama Ana dalam kelompok A adalah 1, dan seterusnya. Begitu pula untuk kelompok B, C, sampai I.

3. Penugasan dosen kepada kelompok secara sukarela 
Dosen menawarkan kepada setiap kelompok untuk maju secara sukarela. Misal kelompok B bersedia maju, maka salah satu anggota mewakili maju berdasarkan nomor inisialnya. Pemilihan anggota yang maju berdasarkan undian nomor anggota kelompok. Dengan demikian, peneliti mengharapkan kelemahan pada model pembelajaran kooperatif tipe NHT dapat teratasi, karena anggota tiap kelompok maju secara sukarela, dan seluruh anggota sudah harus siap. Dengan demikian, anggota dalam kelompok yang memiliki kemampuan lebih dapat bertukar ilmu dengan teman-temannya yang lain dalam satu kelompok.

4. Penilaian satu untuk semua, artinya nilai untuk perwakilan mahasiswa yang maju berlaku bagi nilai satu kelompok.

Kelompok yang maju meskipun hanya diwakili salah satu anggotanya, anggota yang lain juga akan mendapat nilai yang sama.

5. Diskusi antar kelompok dengan yang bertanya

Setelah maju dan menjelaskan, mahasiswa lain dipersilakan bertanya. Mahasiswa yang bertanya akan mendapat poin penilaian individu.

Model pembelajaran kooperatif tipe NHT with Random Name Number memiliki keunggulan dalam hal soal yang diberikan kepada mahasiswa. Pada model pembelajaran kooperatif tipe NHT with Random Name Number, mahasiswa untuk menjawab karena mahasiswa ketika maju tidak ditunjuk dosen. Mahasiswa juga mendapat reward lebih nyata yaitu diberikan nilai tugas bagi keaktifan mereka maju tersebut. Reward ini diberikan kepada satu kelompok dimana mahasiswa yang maju, atau menjadi nilai bersama satu kelompok. Hal tersebut mendorong semua anggota kelompok harus siap maju, ketika satu kelompok bersedia maju, karena yang maju merupakan anggota yang dipilih acak dari undian. Peneliti mengharapkan dari sistem tersebut, ada transfer ilmu antara semua anggota kelompok. Semua mahasiswa juga akan memperhatikan semua paparan bagi mahasiswa yang maju karena mahasiswa yang tidak maju diminta memberi tanggapan bagi yang maju dan juga mendapat reward point jika bertanya.

Tujuan diadakan penelitian ini yaitu bertujuan melihat berapa hasil belajar mahasiswa dimana diterapkan model pembelajaran kooperatif tipe NHT with 
Random Name Number di kelasnya, kedua yaitugunamemperoleh hasil apakahada tidaknya pengaruh model pembelajaran kooperatif tipe NHT with Random Name Number terhadap hasil belajar matematika mahasiswa prodi Pendidikan Matematika angkatan 2019 pada mata kuliah Aljabar Elementer, ketiga adalah menghitung berapakah besarnya pengaruh model pembelajaran kooperatif tipe NHT with Random Name Number terhadap hasil belajar matematika mahasiswa prodi Pendidikan Matematika angkatan 2019 pada mata kuliah Aljabar Elementer, jika ada pengaruhnya.

\section{METODE PENELITIAN}

Pada penelitian ini, desain penelitian yang dipakai adalah Quasi Eksperimental Design atau biasa dinamai dengan eksperimen semu. Usaha yang dilakukan dalam mengakali variabel penelitian pada penelitian eksperimen merupakan keunikan pokok dalam berjalannya prosedur penelitian eksperimen.

Populasi penelitian ini adalah mahasiswa angkatan 2019 kelas A, B, C prodi Pendidikan Matematika Universitas PGRI Adi Buana Surabaya. Selanjutnya, sampel dipilih berdasarkan populasi (Sandri, 2018). Dalam penelitian ini, digunakan teknik purposive sampling untuk menetapkan sampel namun masih mempertimbangkan suatu hal tertentu, misal menetapkan sampel berdasarkan nilai mean mahasiswa yang hampir sama di antara kedua kelas yang dipilih dengan melakukan pretest terlebih dahulu. Pada penelitian ini, peneliti memanfaatkan dua kelas yaitu kelas 2019 A dan kelas 2019 C, dengan kelas 2019 C berkedudukan sebagai kelas eksperimen sedangkan kelas 2019 A sebagai kelas kontrol. Materi untuk pengambilan data pada penelitian ini adalah materi dalam mata kuliah Aljabar Elementer.

Design penelitian yang digunakan dalam penelitian ini adalah posttest control design. Design penelitian ini menggunakan dua kelas untuk mendapatkan signifikansi keterkaitan antara variabel yang diteliti yaitu signifikansi perbedaan antara model pembelajaran yang mengarahkan mahasiswa agar belajar secara kelompok (kooperatif tipe NHT with Random Name Number) ketika ikut dalam pembelajaran di kelas eksperimen, dengan model pembelajaran konvensional di kelas kontrol. 
Tabel 1. Desain Penelitian

\begin{tabular}{ccc}
\hline Kelompok/Kelas & Perlakuan/Treatment & Posttest \\
\hline Eksperimen & $\mathrm{X}$ & $\mathrm{O}_{1}$ \\
Kontrol & - & $\mathrm{O}_{1}$ \\
\hline
\end{tabular}

Keterangan: $\mathrm{O}_{1}$ : Posttest

- : tanpa perlakuan.

$\mathrm{X}$ : diberi perlakuan pada kelas berupa model pembelajaran kooperatif tipe NHT with Random Name Number

Berdasarkan Tabel 1, variabel bebas dalam penelitian ini adalah model pembelajaran kooperatif tipe NHT with Random Name Number, selanjutnya disebut sebagai X. Sedangkan variabel terikat yaitu hasil belajar berupa nilai Ujian Akhir Semester (UAS) mata kuliah Aljabar Elementer disebut sebagai variabel Y.

Data diperoleh dengan langkah pertama yaitu memberikan perlakuan pada dua kelas, yaitu kelas kontrol dengan model pembelajaran konvensional, dan kelas eksperimen dengan model pembelajaran kooperatif tipe NHT with Random Name Number. Model pembelajaran kooperatif tipe NHT with Random Name Number atau model pembelajaran konvensional yang diterapkan pada kelas eksperimen maupun kontrol sesuai dengan model pembelajaran yang ditetapkan tanpa intervensi model pembelajaran yang lain selama satu semester penuh. Setelah itu, subjek penelitian diberi posttest pada materi Aljabar Elemeter. Data penelitian ini adalah nilai dari hasil posttest tersebut. Subyek penelitian diberikan tes berupa tes uraian saat UAS. Sebelum diadakannya UAS pada kelas eksperimen dan kelas kontrol, soal-soal UAS terlebih dahulu dicek validitas dan reliabilitasnya.

Secara statistik, metode analisis yang digunakan untuk mendapatkan koefisien perbedaan diantara kedua buah distribusi data nilai UAS adalah analisis uji-t (t-test) yang dihitung menggunakan Microsoft Excel. Sebelum uji t dilakukan, dilakukan terlebih dahulu uji prasyarat yaitu homogenitas dan kenormalan data nilai UAS.

Uji homogenitas dilaksanakan berdasarkan nilai UAS Aljabar Elementer yang diperoleh mahasiswa di kelas 2019 A dan 2019 C semester Ganjil. Oleh 
karena itu, uji homogenitas variansi yang dapat dilakukan adalah dengan cara menghitung harga $F_{\max }$. Sedangkan uji normalitas juga diperlukan untuk menetapkan data berdistribusi normal atau tidak. Metode statistika yang digunakan adalah uji Lilliefors.

Setelah didapat hasil bahwa data tersebut memiliki distribusi normal dan homogen, prosedur berikutnya yaitu memeriksa hipotesis penelitian dengan mempergunakan analisis uji-t yang sesuai dengan hasil pengujian kenormalan dan kehomogenan data yang digunakan sebagai sampel. Uji-t dilakukan dengan prosedur sebagai berikut:

1. Menetapkan hipotesis, yaitu :

$H_{o}=$ tidak ada pengaruh yang signifikan antara model pembelajaran kooperatif tipe NHT with Random Name Number terhadap hasil belajar matematika pada materi Aljabar Elementer.

$H_{a}=$ ada pengaruh yang signifikan antara model pembelajaran kooperatif tipe NHT with Random Name Number terhadap hasil belajar matematika pada materi Aljabar Elementer.

2. Menghitung nilai t-empirik $\left(t_{e}\right)$ atau t-hitung.

3. Membandingkan nilai $t_{e}$ yang diperoleh dengan nilai t-teoritik $\left(t_{r}\right)$ atau t-tabel dengan ditentukan terlebih dahulu derajat kebebasan $(\mathrm{db})$ menggunakan rumus $d b=N-2$ dan taraf signifikansi 5\%. Jika nilai $t_{e}<t_{r}$, maka tidak ada pengaruh yang signifikan antara model pembelajaran kooperatif tipe NHT with Random Name Number terhadap hasil belajar matematika, dengan kata lain $H_{o}$ diterima. Namun, apabila nilai $t_{e}>t_{r}$, maka terdapat pengaruh yang signifikan antara model pembelajaran kooperatif tipe NHT with Random Name Number terhadap hasil belajar matematika, atau $H_{a}$ diterima.

\section{HASIL PENELITIAN DAN PEMBAHASAN}

Nilai yang diperoleh pada kelas kontrol diberikan pada Tabel 2. Apabila dicermati hasil nilai posttest pada kelas yang diberlakukan model pembelajaran konvensional, rentang dari nilai maksimum ke minimum sangat jauh yaitu 100 dan 55. Besarnya perbedaan nilai sampel dengan rata-rata dapat dilihat dari tinggi 
rendahnya standar deviasi pada kelompok ini. Pada Tabel 2, standar deviasi yang dihasilkan dari nilai posttest pada kelas kontrol adalah 13,98801. Besar standar deviasi ini termasuk tidak terlalu tinggi, yang berarti perbedaan nilai pada kelas kontrol antar mahasiswa tidak terlalu jauh.

Tabel 2. Nilai Statistik Deskriptif Hasil Posttest pada Kelas Kontrol

\begin{tabular}{lc}
\hline \multicolumn{1}{c}{ Statistik } & Nilai Statistik Posttest \\
\hline Nilai paling rendah & 55 \\
Nilai paling tinggi & 100 \\
Nilai rata-rata/mean & 86.04545 \\
Standar Deviasi & 13.98801 \\
\hline
\end{tabular}

Adapun statistik deskriptif dari nilai UAS Aljabar Elementer pada kelas eksperimen diberikan pada Tabel 3.

Tabel 3.Nilai Statistik Deskriptif Hasil Posttest pada Kelas Eksperimen

\begin{tabular}{lc}
\hline \multicolumn{1}{c}{ Statistik } & Nilai Statistik Posttest \\
\hline Nilai paling rendah & 33 \\
Nilai paling tinggi & 96 \\
Nilai rata-rata/mean & 79,125 \\
Standar Deviasi & 13,81451 \\
\hline
\end{tabular}

Tabel 3 merupakan hasil nilai posttest pada kelas yang diterapkan model pembelajaran kooperatif tipe NHT with Random Name Number. Apabila dicermati, rentang dari nilai maksimum ke minimum juga sangat jauh yaitu 96 dan 33. Sedangkan keberagaman nilai posttest dilihat dari standar deviasinya juga termasuk besar yaitu 13,81451.

Berdasarkan Tabel 2 dan 3, terlihat nilai tertinggi yang dicapai kelas kontrol lebih tinggi dibandingkan nilai tertinggi pada kelas eksperimen. Nilai terendah yang dicapai kelas eksperimen lebih rendah dari kelas kontrol. Rata-rata nilai kelas kontrol lebih tinggi dari kelas eksperimen. Berdasarkan analisa statistik deskriptif, model pembelajaran yang diterapkan di kelas kontrol lebih berhasil daripada model pembelajaran yang diterapkan di kelas eksperimen, yaitu model pembelajaran kooperatif tipe NHT with Random Name Number. 
Untuk mengetahui ada tidaknya pengaruh yang lebih baik, dilakukan uji analisis data dengan statistik inferensial. Langkah pertama adalah melakukan uji normalitas dengan tujuan mendeteksi apakah data sampel tersebut merupakan data yang berdistribusi normal. Hasil uji normalitas menggunakan metode Liliefors dengan bantuan Microsoft Excel, yaitu $L_{\text {hitung }}<L_{\text {tabel }}$ atau $0.159235<0.173$ untuk kelas kontrol, sehingga data sampel pada kelas kontrol berdistribusi normal. Sedangkan untuk kelas eksperimen, $L_{\text {hitung }}<L_{\text {tabel }}$ atau $0.139546<0.213$, sehingga data sampel pada kelas eksperimen juga berdistribusi normal.

Langkah berikutnya adalah memeriksa homogenitas data baik dari kelas control maupun eksperimen menggunakan uji F dengan Microsoft Excel, diperoleh hasil pada Tabel 4.

Tabel 4. F-Test Two-Sample for Variances

\begin{tabular}{ccc}
\hline & Variable 1 & Variabel 2 \\
\hline Mean & 86,22727273 & 79,125 \\
Variance & 184,5649351 & 201,7167 \\
Observations & 22 & 16 \\
$d f$ & 21 & 15 \\
$F$ & 0,914971173 & \\
$P($ F $<$ f) one-tail & 0,416651459 & \\
$F$ Critical one-tail & 0,459628619 & \\
\hline
\end{tabular}

Kriteria pengujian kehomogenitasan yang didapatkan dalam penelitian ini ternyata $F_{\text {hitung }}=0,914971173>0,459628619=F_{\text {tabel }}$ pada taraf nyata dengan $F_{\text {tabel }}$ didapatkan dari distribusi F dimana derajat kebebasan setiap data harus cocok dengan $d k$ pembilang dan $d k$ penyebut pada taraf $\alpha=0,05$. Perihal tersebut mengakibatkan data yang dianalisis sebagai sampel penelitian dari kelas kontrol dan kelas ekperimen bersifat tidak homogen.

Oleh karena itu, langkah selanjutnya yang diambil sebagai langkah menganalisis data ini dapat dilanjutkan ke uji-t dengan rumus separated variance. Ketika kita menggunakan Microsoft Excel maka pada pilihan data analisis, kita pilih uji t-test: two-sample assuming unequal variances dikarenakan data sampel penelitian bersifat tidak homogen. 
Setelah dilakukan data analisis menggunakan Microsoft Excel ketika dilakukan uji t-tes: two-sample assuming unequal variances terhadap data yang digunakan sebagai sampel penelitian, yaitu nilai UAS kelas 2019 A dan 2019 C sebagai berikut:

Tabel 5. t-Test Two-Sample Assumming Equal Variances

\begin{tabular}{ccc}
\hline & Variable 1 & Variabel 2 \\
\hline Mean & 86,22727273 & 79,125 \\
Variance & 184,5649351 & 201,7166667 \\
Observations & 22 & 16 \\
Hypothesized Mean Different & 0 & \\
t -Stat & 32 & \\
$P(T<=t)$ one-tail & 1,549968195 & \\
$t$ Critical one-tail & 0,065491935 & \\
$P(T<=t)$ two-tail & 1,693888748 & \\
$t$ Critical two-tail & 0,130983869 & \\
\hline
\end{tabular}

Apabila diperhatikan Tabel 5, t-hitung $=1,549968195<1,693888748=\mathrm{t}-$ tabel, maka didapat hipotesa $\mathrm{H}_{0}$ yang diterima. Dengan demikian bisa disimpulkan bahwa memang tidak ada pengaruh yang signifikan model pembelajaran kooperatif tipe NHT with Random Name Number terhadap hasil belajar matematika pada mata kuliah Aljabar Elementer. Bahkan nilai rata-rata kelas kontrol lebih baik dari pada kelas eksperimen.

Meskipun demikian, berdasarkan jumlah mahasiswa yang mencapai nilai ketuntasan (>70), jumlah mahasiswa pada kelas kontrol yang mencapai nilai ketuntasan sebanyak 17 mahasiswa (77,2\%) dengan nilai minimum 59 diperoleh 1 mahasiswa. Sedangkan pada kelas eksperimen yang mengaplikasikan model pembelajaran kooperatif tipe NHT with Random Name Number sebanyak 15 mahasiswa (93,75\%) dengan nilai minimum 33 yang diperoleh 1 mahasiswa. Tampak dari sisi pencapaian mahasiswa, jauh lebih baik mahasiswa yang berada di kelas yang mengaplikasikan model pembelajaran kooperatif tipe NHT with Random Name Number. 
Secara keseluruhan dari berbagai segi, disimpulkan bahwa kelas yang menggunakan model pembelajaran konvesional sedikit lebih baik jika diperbandingkan kelas yang menggunakan model pembelajaran kooperatif tipe NHT with Random Name Number. Faktor penyebabnya yaitu aturan atau sistem yang diterapkan pada kelas eksperimen dan kelas kontrol, serta kemampuan mahasiswa yang mengikuti perkuliahan di kelas kontrol dan kelas ekperimen. Kemampuan mahasiswa yang dimaksud adalah mahasiswa hanya diminta mengerjakan secara individu terhadap semua tugas yang diberikan. Untuk mahasiswa di kelas kontrol, mereka lebih bisa bekerja secara individu. Sedangkan pada kelas ekperimen, model pembelajaran kooperatif tipe NHT with Random Name Number menuntut mahasiswa bekerja secara kelompok.

Kekurangan lain dalam penelitian ini adalah waktu pembelajaran pada kelas eksperimen yang merupakan kelas malam lebih singkat daripada kelas pagi sehingga, penerapan model pembelajaran kooperatif tipe NHT with Random Name Number sedikit terhambat. Mahasiswa yang dipanggil secara acak untuk mempresentasikan hasil diskusi kelompok, ternyata hanya memperoleh jawaban dari anggota kelompoknya yang lain tanpa memahaminya terlebih dahulu. Model pembelajaran ini seharusnya bertujuan untuk menjadikan mahasiswa saling berbagi ilmu antar anggota kelompok sebelum salah satu mahasiswa diminta maju ke depan kelas. Namun, hal tersebut tidak dapat terlaksana dengan baik. Selain itu, mahasiswa di kelas eksperimen merupakan mahasiswa yang bekerja sampai sore hari, sehingga konsentrasi ketika mengikuti perkuliahan tidak sebaik ketika kuliah yang dilakukan di pagi hari bagi mahasiswa yang tidak bekerja. Oleh karena itu, ke depannya dapat dilakukan penelitian dengan pemilihan kelas yang lebih baik lagi dan lebih identik baik untuk kelas eksperimen dan kelas kontrol.

\section{SIMPULAN}

Menurut hasil dan pembahasan yang diperoleh dapat dibuat kesimpulan bahwa model pembelajaran kooperatif tipe NHT with Random Name Number sedikit lebih baik dibandingkan menggunakan model pembelajaran konvensional jika ditilik dari jumlah mahasiswa yang mencapai nilai ketuntasan. Meskipun kesimpulan dari hasil uji t Two-Samples Assumming Equal Variances adalah tidak 
ada pengaruh yang signifikan antara penerapan model pembelajaran kooperatif tipe NHT with Random Name Number terhadap hasil belajar matematika pada materi Aljabar Elementer. Apabila dilihat dari rata-rata kelas yang diperoleh, hasil pada kelas kontrol lebih baik dibanding kelas eksperimen yang menerapkan model pembelajaran kooperatif tipe NHT with Random Name Number. Faktor penyebabnya adalah aturan atau sistem yang diaplikasikan pada kelas eksperimen dan kelas kontrol serta kemampuan mahasiswa yang mengikuti perkuliahan di kelas kontrol dan kelas ekperimen. Selain itu, pemiliha kelas menjadi kekurangan dalam penelitian ini. Mahasiswa pada kelas eksperimen merupakan mahasiswa yang bekerja sampai sore, sehingga konsentrasi mahasiswa ketika mengikuti perkuliahan tidak sebaik ketika kuliah yang dilakukan di pagi hari bagi mahasiswa yang tidak bekerja.

\section{DAFTAR PUSTAKA}

Angraeni, L., \& Puspitasari, H. (2019). Pengaruh media simulasi komputer terhadap hasil belajar mahasiswa pada materi kinematika gerak. Jurnal Pendidikan Matematika dan IPA, 10(1), 1-10. https://doi.org/10.26418/jpmipa.v10i1.29659

Arifin, F., \& Herman, T. (2018). Pengaruh pembelajaran e-learning model web centric course terhadap pemahaman konsep dan kemandirian belajar matematika siswa. Jurnal Pendidikan Matematika, 12(2), 1-12.

Bainamus, P. M., Hartanto, \& Abdullah, M. I. (2017). Pengaruh model pembelajaran hibrid matematika pada sekolah menengah pertama negeri 1 Curup Tengah. Jurnal Pendidikan Matematika, 11(2), 16-23. http://dx.doi.org/10.22342/jpm.11.2.3367.

Dadri, P. C. W., Dantes, N., \& Gunamantha, I. M. (2019). Pengaruh model pembelajaran kooperatif tipe NHT terhadap kemampuan berpikir kritis dan hasil belajar matematika siswa kelas V SD Gugus III Mengwi, PENDASI: Jurnal Pendidikan Dasar Indonesia, 3(2), 84-93.

Lakkas, M. (2018). Pengaruh model pembelajaran kooperatif terhadap motivasi dan hasil belajar siswa pada materi sistem koloid SMAN 4 Bantimurung Maros. PEMBELAJAR: Jurnal Ilmu Pendidikan, Keguruan, Dan Pembelajaran, 2(1), 12-24. https://doi.org/10.26858/pembelajar.v2i1.4135

Lestari, N., Hartono, Y., Purwoko, P. (2016). Pengaruh pendekatan open-ended terhadap penalaran matematika siswa sekolah menengah pertama palembang. Jurnal Pendidikan Matematika, 10(1), 81-95. http://dx.doi.org/10.22342/jpm.10.1.3284.81-95

Madio, S. S. (2016). Pengaruh pembelajaran berbasis masalah terhadap kemampuan penalaran dan komunikasi matematis siswa SMP dalam matematika. Jurnal Pendidikan Matematika, 10(2), 1-16. https://doi.org/10.22342/jpm.10.2.3637.93-108

Nurdyanto, H. E., Indana, S., \& Agustini, R. (2018). Pengaruh penerapan model 
pembelajaran kooperatif tipe NHT dengan pendekatan spices continuing terhadap keterampilan berpikir kritis dan hasil belajar siswa SMP. Jurnal Penelitian Pendidikan IPA, 2(2), 58-65. https://doi.org/10.26740/jppipa.v2n2.p58-65

Putri, N. A. (2017). Pengaruh model pembelajaran kooperatif tipe STAD (students teams achievement division) terhadap hasil belajar IPS peserta didik kelas V MIN 6 Bandar Lampung. Lampung: UIN Raden Intan Lampung.

Rahmiati, R., \& Fahrurrozi, F. (2016). Pengaruh pembelajaran missouri mathematics project (MMP) terhadap kemampuan pemecahan masalah matematika. Jurnal Pendidikan Matematika, 10(2), 1-12. https://doi.org/10.22342/jpm.10.2.3634.75-86

Rumapea, R. (2018). Pengaruh model pembelajaran kooperatif tipe STAD dan pemberian soal open-ended terhadap kemampuan pemecahan masalah matematis siswa ditinjau dari kemampuan awal matematika. Jurnal Pendidikan Matematika, 12(1), 1-14.

Sandri, M. (2018). Pengaruh media lagu terhadap hasil belajar matematika pada materi sifat-sifat bangun datar siswa kelas 5 SD negeri 5 Kota Bengkulu. JNPM (Jurnal Nasional Pendidikan Matematika), 2(1), 1-8. https://doi.org/10.33603/jnpm.v2i1.698

Suparni, N. (2017). Pengaruh model pembelajaran kooperatif tipe jigsaw terhadap hasil belajar matematika siswa kelas $V$ SD negeri 1 Metro Timur. Lampung: Universitas Lampung.

Sutriningsih, N., Pratiwi, R., \& Utami, B. H. S. (2018). Penerapan model pembelajaran kooperatif tipe numbered head together (NHT) pada materi sistem persamaan linear dua variabel (SPLDV). JURNAL E-DuMath, 4(2), 11-20. https://doi.org/10.26638/je.717.2064 